\title{
Examining the Relationship between Information Systems, Sustainable SCM, and Competitive Advantage
}

\author{
Asterios Stroumpoulis ${ }^{1, *}$, Evangelia Kopanaki ${ }^{1}(\mathbb{D})$ and George Karaganis ${ }^{2}$ \\ 1 Department of Business Administration, University of Piraeus, 18534 Piraeus, Greece; evik@unipi.gr \\ 2 Last Mile Logistics, Magoula 19600, Greece; gkaraganis@gmail.com \\ * Correspondence: stergiostrou@unipi.gr
}

Citation: Stroumpoulis, A.;

Kopanaki, E.; Karaganis, G.

Examining the Relationship between

Information Systems, Sustainable

SCM, and Competitive Advantage.

Sustainability 2021, 13, 11715.

https://doi.org/10.3390/su132111715

Academic Editors: Hyo Jung

(Julie) Chang, Stacy H. Lee and

Seoha Min

Received: 24 August 2021

Accepted: 18 October 2021

Published: 23 October 2021

Publisher's Note: MDPI stays neutral with regard to jurisdictional claims in published maps and institutional affiliations.

Copyright: (c) 2021 by the authors. Licensee MDPI, Basel, Switzerland. This article is an open access article distributed under the terms and conditions of the Creative Commons Attribution (CC BY) license (https:/ / creativecommons.org/licenses/by/ $4.0 /)$.

\begin{abstract}
Sustainability, information systems (IS), and sustainable supply chain management (SSCM) are the main research areas of this study. In an era where environmental and social responsibility is becoming increasingly more important, SSCM is very significant for the survivability and competitiveness of organizations. Information systems may facilitate sustainable practices, as they support supply chain processes, decrease costs, and enable the control and monitoring of operations. The aim of this research is to explore the relationship between information systems and SSCM and explain under what circumstances they could lead to competitive advantage or increase internal business performance. To analyze the above, the methodology comprises a literature review enabling the understanding and conceptualization of the main research constructs and revealing the gaps of previous research. It also comprises qualitative research based on a single-case study allowing an in-depth examination of the subject of study. The findings reveal that the use of information systems, combined with strong interorganizational relationships and collaboration, can support SSCM practices. They can bring important business advantages, such as improved business performance and increased customer loyalty, but not necessarily competitive advantage. The results of this research show that SSCM is a promising field of study, with prospects for future research.
\end{abstract}

Keywords: information systems; sustainable development; sustainable supply chain management; competitive advantage; business performance

\section{Introduction}

Contemporary companies are often part of large and complex supply chains and need to use various information systems in order to improve their operations, support their collaboration with trading partners, and potentially gain competitive advantage in their industry. Supply chain management helps companies to improve interorganizational transactions, as well as to monitor the flow of materials, products, and information from the producer to the consumer [1].

In addition, contemporary companies face many social and environmental pressures, reinforcing the need to develop a philosophy and culture of sustainable development in order to survive and potentially gain competitive advantage. Sustainable development focuses on three main pillars, which are the environment, the society, and the economy [2]. The global environmental problem, the growing environmental consciousness of consumers, and the inequities in society led to the development of sustainable supply chain management (SSCM). SSCM is very significant, as it may provide advantages to all companies in a supply chain, such as cost savings, support for environmental practices, human capital development, and the satisfaction of customers [3].

In the recent years, the evolution of technology and the expansion of the use of the internet in the operations of companies have led to the growing use of information systems in the field of supply chain management [4]. The internet has boosted the interconnection of companies by providing low-cost, easy, and real-time communication and connectivity 
between organizations and trading partners. Therefore, information systems have become significant parts of supply chain management, as they facilitate collaboration and support the internal and external processes of a company, as well as increase their performance [5]. They also facilitate collaboration and may lead to the development of sustainable practices.

According to the literature, the use of information systems is imperative both for the efficient operation of a company and for the support of sustainable practices. Although the role of information systems in the development of SSCM has been extensively examined in the literature, the impact of their combination on companies and on supply chains is still unclear. Even more unclear is whether this combination can lead to competitive advantage. On the one hand, there are authors supporting the notion that the integration of information systems into SSCM leads to increased business performance (without mentioning the ability to gain competitive advantage) [5-10], while, on the other hand, there are studies supporting the notion that this combination enables supply chains or companies to achieve a sustainable competitive advantage [11-15]. Therefore, different views can be identified in the literature concerning the impact of IS-enabled sustainability practices on the attainment of competitive advantage or only of business performance.

The objective of this research is to clarify and address these issues by answering the following questions:

"What is the relationship between the use of information systems and SSCM?"

"What is the impact of their combination on companies and supply chains?"

"Can this combination lead to competitive advantage?"

Therefore, the aim of this study is not only to explain the relationship between the use of information systems and the development of sustainability practices in a supply chain but also to examine the impact of their combination on companies and supply chains. An additional aim is to examine whether this combination could enable companies, besides attaining business performance, to also gain competitive advantage.

To address these issues, a literature review was primarily conducted to clarify the definitions and concepts under study. The literature review enabled us to reveal the above research gap as well as to examine the advantages and impact of information systems. An interpretive approach and a single-case study design were then followed to enable an in-depth analysis of the subject of study. The case study was conducted at a modern 3PL company in Greece, and empirical data were collected through open-ended interviews and limited participant observation. A qualitative method of data analysis was then carried out based on the resource-based view (RBV) theory and on a conceptual framework developed by Dao et al. [11]. The results of this study are in line with the conclusions of previous research focusing on the increase in business performance. While the investigated company gained many benefits from the use of information systems and the development of sustainable practices, it failed to attain competitive advantage. However, it increased its business value and strengthened its customers' loyalty. Nevertheless, the results enabled us to understand and discuss under what circumstances competitive advantage may also be gained.

\section{Sustainable Supply Chain Management and Information Systems}

This research analyzes the subjects of information systems and SSCM. It also examines how their combination could enable companies to increase their business performance and/or gain competitive advantage. To identify, examine, and clarify the concepts examined in this study, it was essential to conduct a literature review.

The literature review allowed us to examine and understand the main concepts and theories associated with the phenomenon under study. It also enabled us to develop a conceptual framework that presents the main factors that enable a company to either increase its performance and/or achieve competitive advantage. 


\subsection{Sustainable Development}

The definition of sustainable development was initially developed by the Brundtland Commission. It refers to the "ability to make development sustainable, ensuring that it meets the needs of the present, without compromising the ability of future generations to meet their own needs". This is the most commonly and frequently used definition in the international literature [16]. It is based on the idea that the desired outcome for society can be achieved when the use of resources and the living conditions continue to meet human needs, without undermining the ecosystem integrity and stability [17].

In 2002, in the World Summit on Sustainable Development, an expansion of the original definition of the term was developed, including the definition of the three pillars of sustainable development [18]. Hence, sustainable development is a complex and multidimensional system [19] that focuses on different pillars, comprising the environment, the society, and the economy [18]. It is a process that pushes the evolution and transformation of these three pillars (Figure 1) for a better quality of life [20].

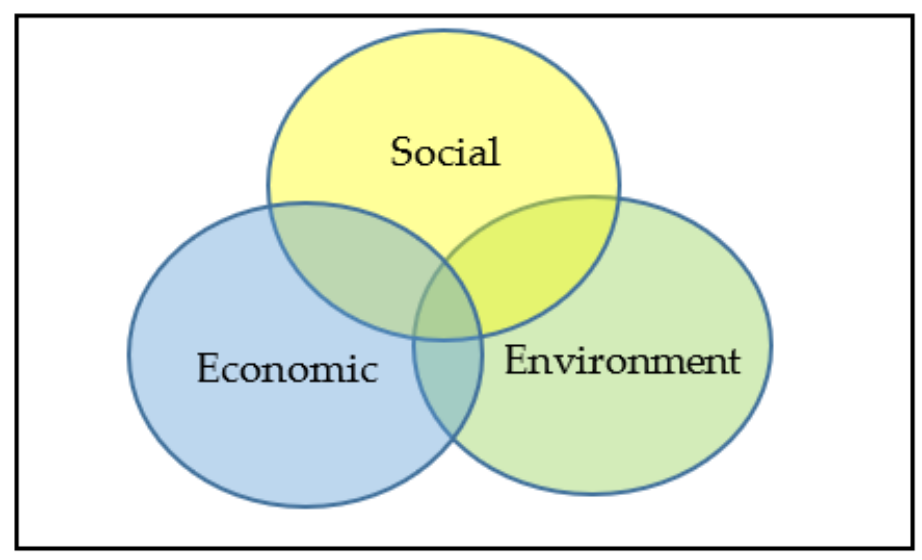

Figure 1. The 3 pillars of sustainability [21].

In order to increase their economic goals, organizations need to realize that they are part of a larger natural and task environment where they operate. During the last decades, firms had the belief that their corporate responsibility was only associated with financial information, while qualitative information of social and environmental issues was not reported. However, during the last years, this situation has changed, and qualitative information of non-financial issues is now reported, as companies, shareholders, and stakeholders have realized that social and environmental matters affect the sustainability of their companies. This recent interest in social and environmental sustainability reporting is very important, as customers or other organizations are in a position to examine and evaluate the way companies manage these important issues through their operations [22].

Therefore, firms must behave in an environmentally and socially sustainable manner [23]. According to the above, there is an increasing pressure on firms to consider their social and environmental impact [24]. Furthermore, because of the current situation of the natural environment and the policies that the UN and the EU have developed, companies are obliged to follow the Sustainable Development Goals (SDGs) so as to produce a more sustainable planet for future generations [25].

Moreover, companies often want to embrace such policies to improve their branding and attain competitive advantage [26]. As customers may have different preferences regarding services and products, as well as different ecological and social needs, companies have to understand the preferences of their target groups to offer competitive services [27].

According to Choi and $\mathrm{Ng}$ [28], the analysis of sustainability has mostly focused on each pillar separately, despite the fact that the three dimensions of sustainability are interrelated. Environmental sustainability has been very important for our society and for corporations since the 1980s, where many crucial environmental issues have been developed. In order to achieve the desired level of environmental sustainability, companies 
should create and develop business capabilities in order to increase their performance, while decreasing the negative effect of their business operations on the natural environment [29].

The emphasis on the social dimension of sustainability appeared later, referring to the wellbeing of people and society. According to Davidson [30], social sustainability describes the situation of social welfare and policy. However, Boström [31] supports the notion that the meaning of social sustainable development is still unclear, and this definition must be framed and filled with content. As Mani et al. [32] suggest, there are theories associated with the social pillar, such as the stakeholder and legitimacy theories, which can be used to explain a company's efforts for socially sustainable behavior.

The main problem of sustainability is to find a balance among the needs of society and nature in order to support the human way of life [28]. In some studies, social sustainability has been developed only in terms of social relations, which means that the social-environmental relationships and connections have been excluded. As a result, this kind of description of social sustainability has to expand the separation between the social and environmental pillars of sustainability [30]. However, the integration of these pillars is not something that can be done easily [31].

So, researchers should study and develop theoretical frameworks that include all of the pillars of sustainable development in order to export more comprehensive data. After that, they will be in a position to improve the way that companies realize the concept of sustainability and will be closer not only to the natural environment but also to society.

\subsection{Sustainable Supply Chain Management}

Nowadays, firms and stakeholders pay more attention to environmental conditions and the wellbeing of society, especially now due to the pandemic. As a consequence, stakeholders put pressure on companies and on their trading partners to ameliorate their production processes, manage their resource usage, and develop sustainable activities for the good of society [33]. These lead to a growing importance of the development of SSCM [34]. SSCM is very significant, as it may provide advantages to all companies of the supply chain, such as cost savings, support for environmental practices, and competitive advantage [3]. Therefore, it is imperative to incorporate environmental management practices throughout the supply chain, not only to develop a greener supply chain but also to increase profits and market share and, thus, achieve a competitive advantage [35].

The increased importance of SSCM has drawn the attention of many researchers and academics aiming to understand how SSCM affects society and the environment [34]. Over the last years, researchers and scholars have made many attempts to study and examine the sustainability of the supply chain management, but most studies and surveys focused on the environmental and economic dimensions, while very few of them focused on the social one [32].

Nowadays, consumers and stakeholders are more sensitive not only about the environment, requiring corporations to use sustainable processes and produce safe and environmentally friendly products, but also about society [36]. Some scholars proved that many consumers prefer to buy products from firms that are eco-friendly and care more about society [37]. Customers and other stakeholders (in the local society) focus on the final service or product, without distinguishing between the companies of a supply chain. Thus, all companies should follow the same rules so as not to have a negative impact on the 'leading company' and the other partners. This means that the leading company is responsible for its affiliates, as they affect its image and reputation. This also justifies the increased popularity and importance of 'sustainable supply chain management' [2].

The literature review revealed many articles that have developed many definitions in order to examine and clarify the meaning of SSCM. Some of these definitions are presented in Appendix A. The two most prevailing definitions are those of Seuring and Muller [38] and Carter and Roger [39]. The first defines SSCM as "the management of material, information and capital flows as well as cooperation among companies along the 
supply chain while taking goals from all three dimensions of sustainable development" [38] (p. 1700), while the second defines SSCM as "the strategic, transparent integration and achievement of an organization's social, environmental, and economic goals in the systemic coordination of key interorganizational business processes for improving the long-term economic performance of the individual company and its supply chains" [39] (p. 368).

At this point, it is important to mention that SSCM is different from green SCM (GSCM). GSCM focuses only on the environmental pillar, and its main goal is to limit hazardous material and pollution [40]. A lot of GSCM practices have been studied by academics and applied by industries, including green design, green purchasing, green manufacturing, green transportation, and reverse logistics [41]. Thus, SSCM is the extension of GSCM and includes not only the environmental dimension but also the economic and social dimensions [42]. To sum up, researchers should not focus solely on the environmental pillar but should equally examine the other dimensions of the supply chain [43].

SSCM expands traditional supply chain management to embody environmental and social issues. SSCM extends the economic dimension to integrate environmental and social goals [44]. The growing environmental and social concerns have forced companies not only to focus on economic-related goals but also to incorporate a wide variety of objectives in their supply chain decision framework [45]. According to Al-Odeh and Smallwood [46], SSCM could enable companies to improve and increase their performance. Therefore, SSCM is becoming an influential component in the pursuit of achieving sustainable performance [8]. Sustainable supply chain performance depends on innovation and on its specific implementation to support performance [47]. It should be noted that even more innovative and alternative solutions in the field of supply chain management and logistics have been developed during the coronavirus crisis [48].

Nevertheless, all these practices require intensive collaboration and information sharing among business partners. So, it is necessary to develop and use information systems and technologies in supply chains. Information systems could ensure that this collaboration and co-ordination in the entire chain is developed as a single unit [49].

\subsection{Information Systems in SSCM}

Information systems include information technology, processes, people, and organizational structures [50]. All four components are important in order to deliver the information processing functionalities that organizations need [51]. Nowadays, it is not only a challenge, but it is also very important for companies to be innovative and adopt digital technologies [52]. Fiorini and Jabbour [53] support the notion that it is impossible to achieve an effective and efficient supply chain without the use of IT. The complexity of contemporary supply chains forces companies not only to implement advanced information systems but also to adopt online communication systems [54].

Information systems are significant and integral parts not only of companies but also of supply chains. According to Georgopoulos et al. [55], information systems in supply chains aim to (1) unify systems at all stages of the chain, (2) automate processes, (3) manage information flows, and (4) help the planning, organization, and optimization of the core functions of the supply chain.

In the era of Industry 4.0, the digitalization of supply chains is becoming increasingly more important [56]. Industry 4.0 includes new technologies, such as Internet of Things (IoT), big data analytics (BDA), artificial intelligence (AI), and blockchain technology (BT) [57]. These new technologies are able to support the supply chains and help companies to increase their transparency [58].

However, the integration of these technologies comes at a huge cost, which is, apart from the financial cost, the adoption cost due to the low level of IT knowledge and skilled personnel [59]. Companies, in order to understand and realize the full potential of these technologies, must be aligned with all their partners, from producers and farmers to the final consumers and customers. That is the main reason why many transportation companies have not yet invested in such technologies and continue to work with the 
already existing information technologies; they are fully understandable to all supply chain partners [60]. Consequently, it is broadly accepted that Industry 4.0 technologies and applications are still underused [61]. Although many companies have embraced technological solutions, such as advanced IS, RFID or IoT solutions, and cloud-based services, most of them have not reached the level of integration, interconnectedness, and self-configuring capabilities of the network infrastructures required in the Industry 4.0 era [62]. Acknowledging the fact that the level of adoption of such infrastructures is relatively low, the present paper focuses on more common IT solutions and information systems, which are the backbone of supply chains and of 3PL companies.

To better understand the competitive value of the use of IT in SCM, Marinagi et al. [12] conducted a survey examining companies in the area of central Greece. Their research was based on a structured questionnaire, which incorporated several criteria examined in previous empirical studies. The results of this study showed that IT practices and techniques supporting supply chain management are able to lead to a sustainable competitive advantage. They also showed that investments and the implementation of IT could lead to higher profitability and business effectiveness.

According to Peng et al. [5], the adoption of IT can facilitate information sharing and support the internal and external processes of a company, as well as increase business performance. Therefore, the use of technology in SCM focuses both on improving collaboration within and between companies and on increasing performance. According to Gonzalez-Feliu et al. [63], two factors are significantly important in this collaboration: localization (ability of detection and monitoring of a product) and transport (physical transport of any product from point $A$ to point $B$, which are the point of origin and the destination, respectively).

Kagermann et al. [64] stated that the full potential of information technology can only be revealed if all partners collaborate and are willing to share their information. The leading companies of a chain should lead this effort, as small- and medium-sized companies are not able to do so [65]. However, they will have to follow their powerful partners to continue collaborating with them [65]. Business alignment among partners can be further supported by new technologies. For example, blockchain technology is estimated to play a vital role during the next years in the field of supply chain management. Blockchain technology will become an integral part of supply chains and will contribute to the social pillar of sustainability, enabling and supporting the traceability and transparency of the chains [66]. Nevertheless, the full potential of the adoption of this new technology across the supply chain will still not be possible if the partners are not aligned or willing to share information [67].

Therefore, besides enhancing collaboration between companies, information systems also lead to the development of sustainability practices. Information systems are important and integral tools for SSCM and have the ability to bring benefits to all their members, suppliers, and customers [11].

In their study, Wang et al. [28] focused on the impact of IT on sustainable environmental management. Although environmental sustainability is a very significant issue [68], the literature of information systems does not clearly explain the role of information technology. It seems that information technology (IT) is a complex issue, as it may be either a solution or a problem for environmental sustainability. IT has the ability to create opportunities for companies to support green environmental management and develop environmental sustainability [28]. According to Wang et al. [28], IT can be utilized in the management of the environmental pillar in order to support the expansion, improvement, efficiency, and flexibility of a company's environmental processes. By integrating IT into their environmental management activities, firms have the potential to extend their environmental activities to customers and suppliers [69]. Therefore, information systems are an important key factor for achieving environmental sustainability [28].

Apart from the environmental performance of the company, IS also positively influence the operational and financial performance of the company. However, it is still not clear 
how IS could influence the social performance [53]. Saberi et al. [70] support the notion that information systems increase social performance by helping supply chains to improve transparency among partners so as to fight fraud. They also enable customers to obtain reliable information about the services/products that are provided to them [71].

To sum up, the adoption and the use of IT enable a company or a supply chain to develop sustainability practices and increase its performance. However, it is still unclear if these results could also contribute to the attainment of competitive advantage [7] in a sustainable supply chain.

\section{Theoretical Development}

According to Joshi and Li [23], there is unofficial evidence showing that environmental responsibility improves the internal operations of a corporation and increases their efficiency and effectiveness (performance). However, not every company is in a position to implement and benefit from a sustainability strategy. Previous research applying the resource-based view (RBV) theory confirms that firms and organizations with unique resources and capabilities are able to implement sustainability practices and realize the financial benefits from sustainable development [23].

The resource-based view is a theoretical model that focuses on a company's internal environment and examines its resources, which can be the key to increasing the company's performance [72]. Furthermore, if these resources have VRIO characteristics, they may enable the company to gain competitive advantage [73]. According to Cardeal and Antonio [74], the features of VRIO are value, rarity, imitability, and organization.

Dao et al. [11] developed a theoretical framework based on the RBV theory and argued that a commitment to human resource management (HRM), supply chain management (SCM) and information technology (IT) resources enables companies to develop sustainability capabilities. According to Colbert and Kurucz [75], HRM is concerned with resources involving human capital, the social and spiritual capital of the employees, and human interaction and processes. According to Bharadwaj [76], IT resources include tangible, technical components; IT management skills; and intangible IT tools, such as customer knowledge and orientation. IT resources facilitate the coordination among supply chain partners and companies. They also facilitate the development of business capabilities across the supply chain, which could enable companies to increase their profit and potentially gain competitive advantage [77]. Therefore, the combination of IT and HRM resources gives companies unique capabilities that could help them to increase their efficiency, profitability, and innovation capabilities, as well as to obtain competitive advantage [11].

According to the RBV theory, competitive advantage can be additionally created by the capabilities belonging to a supply chain [78]. These capabilities can be developed beyond the boundaries of organizations by combining the resources available with different members of the supply chain [79]. Gold et al. [13] (p. 230) highlight that "partner-focused supply management capabilities may evolve to corporate core competences as competition shifts from an inter-firm to an inter-supply-chain level".

SSCM uses all resources that are included in environmentally aware supply chains, including product development, production, distribution, and reverse logistics [80]. Therefore, as demonstrated in Figure 2, IT, HRM, and SCM resources should be combined so that companies are able to develop sustainability capabilities, which could lead to competitive advantage [11]. 


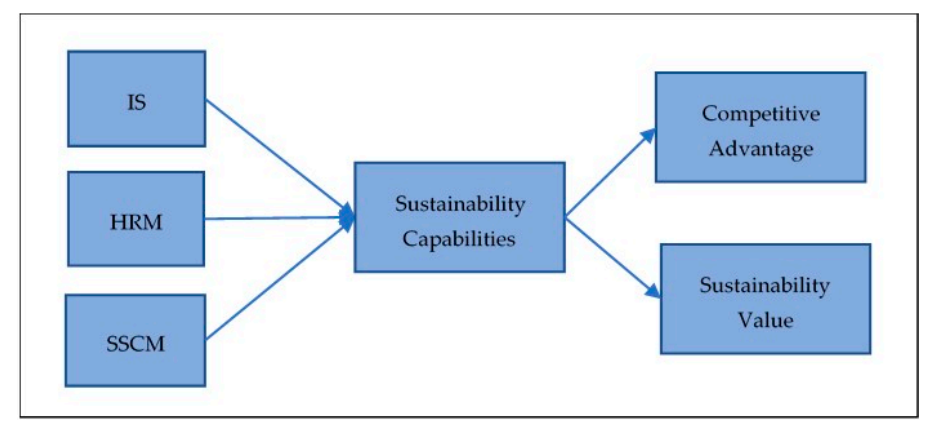

Figure 2. How to create competitive advantage. Source: [21] (p. 96).

Therefore, according to Dao et al. [11], through the collaboration of all members of a sustainable supply chain, resources are able to create additional value for firms and their partners (that are rare and difficult to imitate), because they have emerged from the collaboration and the know-how of the partners, and also help the company to improve the way it operates.

Sustainability capabilities refer to a company's ability to incorporate, develop, and reshape its internal and external capabilities to deal with the rapidly changing environment in terms of the three components of sustainability. These capabilities may refer to certain processes or routines that could combine, recreate, or renew resources into new capabilities as the larger environment develops and changes [81]. Morash [82] supports the notion that these capabilities are the basis of supply chain strategy development and a source for creating a competitive advantage. Therefore, after these "sustainability capabilities" are developed and assimilated with the help of HR, SCM, and IT resources, they lead to sustainability value and competitive advantage, which puts the company and its partners in a position of power in relation to its competitors [11]. Furthermore, Gold et al. [13] state that inter-firm (or SCM) resources and capabilities emerging from partner collaboration within the supply chain can become sources of sustainable competitive advantage. Finally, Baah and Jin [14] argue that SSCM can significantly and positively influence competitive advantage.

To summarize, according to the RBV theory and the analysis conducted by Dao et al. [11], it seems that IT with proper use and utilization in combination with SCM and HR resources, and supported by the right alignment with partners, can create a strong competitive advantage for both the company and its partners. They can also bring sustainability capabilities, leading to improvements at a social, financial, and environmental level.

\section{Methodology}

The aim of this research is to contribute to the understanding of the impact of ITenabled SSCM on companies and their supply chains by using a conceptual theoretical model and testing it through empirical work. This study followed an interpretive approach and adopted a qualitative method of inquiry to examine the impact of IS-enabled SSCM in a specific business context. It also primarily conducted a literature review, which was intended to only investigate and develop the subject bibliographically, without the collection of new data [83].

Therefore, the research conducted in this study comprised the following three phases [84]:

- Review of the literature and identification of the main constructs of a conceptual framework.

- Qualitative study examining the interpretive framework by involving practitioners.

- Review and refinement of the framework. 


\subsection{Literature Review}

A literature review provides information regarding previous and published research, as well as theories related to the subject under examination. It enables researchers to better understand, clarify, and analyze the concepts under study. It also enables them to identify research gaps or different views expressed in the literature [85], as well as guiding the formulation of research questions. Finally, it enables researchers to formulate and support their argument, as well as providing original results [86].

Although the literature review does not constitute the main research methodology, in this paper, the search and the selection of papers were conducted in a systematic way [87]. The steps, followed in the literature review, comprised searching for articles based on keywords, reading the abstracts to narrow article selection, categorizing the articles, clarifying the main concepts and the relationship among them, drawing conclusions, and identifying the gaps and limitations for future research. The steps followed are presented in Figure 3.

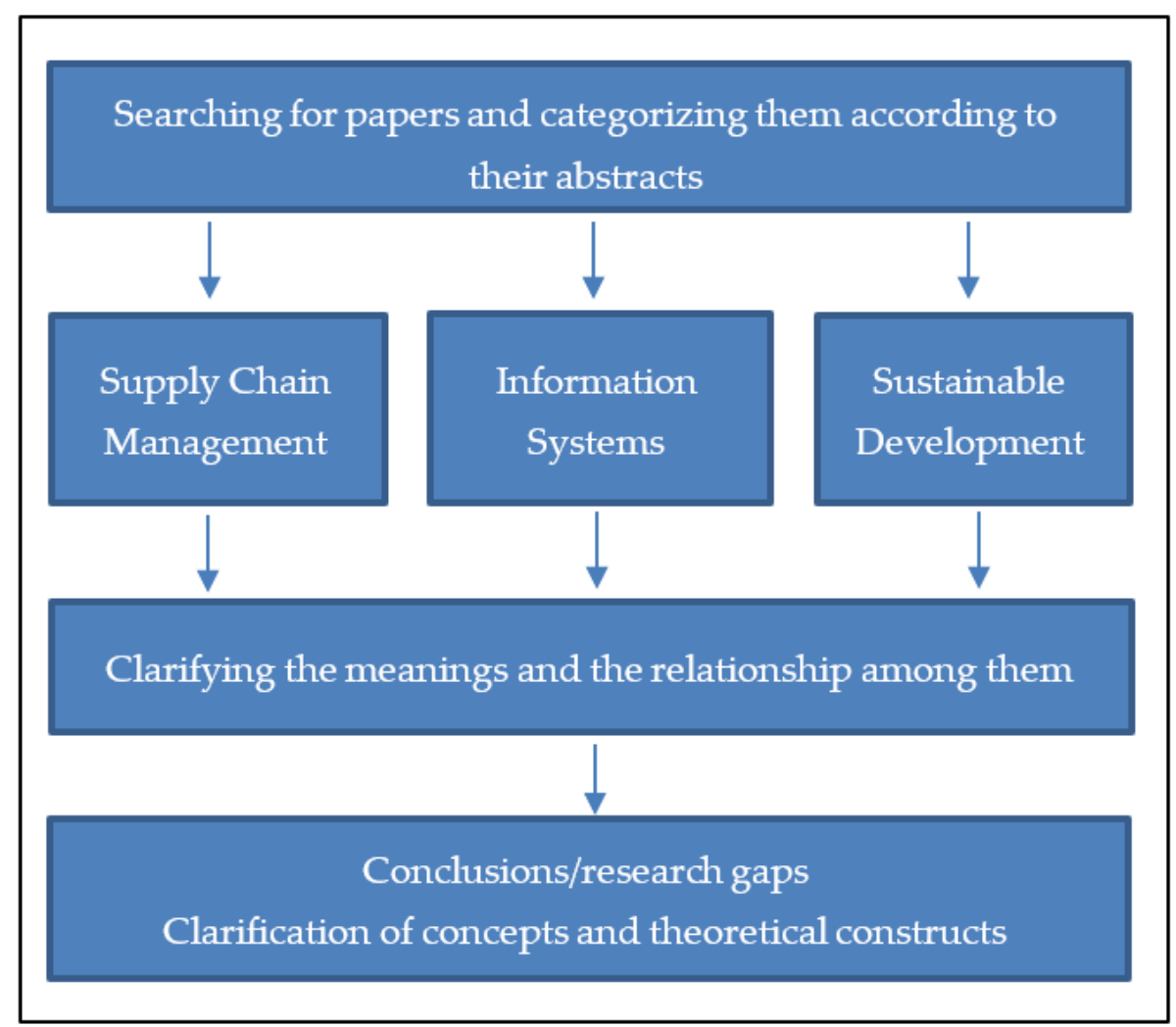

Figure 3. Steps of literature review. Source: [58].

The main platforms/databases used for the search of articles were Scopus and Researchgate. The keywords used in the search were information systems, sustainable development, sustainable supply chain management, business performance, and competitive advantage. The full text of each paper was reviewed and studied so as to exclude those that were not aligned with the concept of this research. The number of papers finally used was 82 papers (nearly $90 \%$ of those originally retrieved) from journals, proceedings of conferences, and books.

The study of the literature revealed that only a limited number of previous studies examined the relationship between information systems, sustainability practices, and competitive advantage [11-15]. It also revealed that many researchers put emphasis on the attainment of business performance [5-10] without examining whether it could also lead to competitive advantage. Furthermore, the review of the literature enabled us to study the theoretical approaches used in the relevant studies. As explained in the previous section, 
the conceptual framework developed by Dao et al. [11], in combination with the RBV and VRIO theoretical models, was chosen as the most appropriate approach to examine the relationship among IT resources, SSCM, and competitive advantage.

\subsection{Qualitative Case Study}

To further examine these issues, we followed an interpretive approach $[88,89]$ and a qualitative research method based on a single-case study. Interpretive approaches enable one to explicitly investigate the context of the phenomenon under study [85]. In order to better understand the context of a study, interpretive researchers investigate the social setting, aiming to learn from the participants' perspectives [90]. Qualitative research methods are often used in interpretive approaches. According to Walsham [91], qualitative methods have the capability to examine in depth the phenomena that are affected by the environment where they are applied. Such phenomena could be the application of specific strategies and green policies or the obtainment of competitive advantage, within specific organizational and business contexts. It can be argued that a qualitative research method is more suitable when the investigation concerns a new field of study or intends to discover and theorize prominent issues [92].

Qualitative research methods have several advantages. Initially, they provide detailed information as well as in-depth knowledge of the subject being examined in a specific business context. Another important advantage is that they give more freedom in the choice of data, as the parties involved can analyze emerging issues in detail besides those raised in the questions [93].

Qualitative methods can be used as case study research in order to examine and clarify one or multiple cases [94]. According to Eisenhardt [95], the case study methodology is appropriate for any research focusing on theory development. It can test existing theoretical concepts/frameworks and relationships and allows the thorough description of phenomena [96]. Therefore, a case study approach is suitable when the phenomenon under examination is unclear or when there is no control over behavioral events [97,98]. The main weakness of qualitative case studies is the lack of generalizability of their results. However, generalizability in qualitative approaches can be attained by theoretical development or the theoretical insight gained though the analysis and understanding of the subject of study [99]. An additional weakness is related to the risk of bias either of researchers or of interviewees. This risk is again counterbalanced through the principles of dialogical reasoning and multiple interpretations [99].

A single-case study design was followed in this research to examine the phenomenon under study in depth; contribute to the theoretical development; and examine whether the combination of technology with sustainability practices, within a specific business context, can lead to competitive advantage. The company selected is a successful 3PL company in Greece, which has adopted a variety of information systems to support its supply chain processes. It has also developed sustainability practices, following the directives of the European Union. An additional reason contributing to the selection of this specific company was the ease of access and consent for the conduct of the study.

In this research, empirical data were collected through semi-structured interviews and limited participant observation. The interview is one of the most useful tools of inquiry for a qualitative method. The main aim of the researcher or of the questionnaire is the extraction of information related to the subject of study, through communication and interaction with the interviewees [100]. Through interviews, the respondent can express emotions and opinions, which help the researcher to understand much more than they would otherwise [93]. Their main tool is the conversation that takes place between two or more people. Oakley [101] supports the notion that in qualitative interviews, practices and standards are not only verified but also questioned, challenged, and reinforced. Qualitative research interviews can be either semi-structured, lightly structured, or in depth. The fundamental characteristic of semi-structured interviews is that they do not have a predetermined flow and, to a large extent, are not directed by the researcher. Moreover, 
through open-ended interviews, the researcher can be directed by specific responses and has the opportunity to raise additional questions to draw safer conclusions [93].

In this research, semi-structured interviews were used as the main method of data collection in the conducted case study. They were chosen as they can provide valuable data and enable an in-depth analysis of the area of study. The aim of the interviews was to examine the relationship, communication, and collaboration of the company with its trading partners; to analyze their adopted sustainability practices; and to further examine the role of their information systems. In order to proceed to the interviews, authors had to first develop a questionnaire, which formed the basis of the discussions conducted with the interviewees. The questionnaire was divided into sections, including sustainability policies and practices (e.g., green transport and distribution), information systems used by the company, collaboration and relationships with trading partners, achieved business results (e.g., process efficiency and competitive performance), future trends, and the company's goals. It should be additionally noted that some of the questions aimed to clarify the relationship of the company's IS with the adoption of sustainable practices.

Interviews were conducted in person with managers and users who were familiar with sustainability goals, supply chain processes, and the use of specific information systems. More specifically, interviews were conducted with the logistics director, the warehouse manager, the IT manager, and an account manager (handling the interaction and processes related to specific customers). Each interview had a duration between $30 \mathrm{~min}$ and two hours. Most of the interviews were tape recorded and entirely transcribed. Moreover, authors took notes during and immediately after the interview as a primary information source. Additional data were collected through documentation and limited participant observation (including unstructured discussions with personnel, such as the warehouse supervisor, during periods of observations). These enabled us to further examine the company's operations and business outcomes supported by specific information systems.

\section{Description of Case Study and Findings}

The case study was conducted at the end of the economic crisis in Greece and prior to the beginning of the COVID-19 pandemic. At that time, companies in Greece were making investments in new technologies, and most of them were focusing on the development of sustainability practices, following the European directives and meeting the expectations/requirements of their customers.

Although Greek companies have lagged behind the adoption of advanced systems (i.e., they may often use more traditional MRP or ERP systems), they have easily adopted technologies to support sustainability (mainly green) practices. Especially the 3PL companies, as the one examined in this study, which have been greatly influenced by their international or multinational partners/customers, collaborating with them and embracing their directions and practices.

The 3PL company studied is a successful company using information systems to support sustainability practices. It specializes in operations and procedures of transportation and warehousing, which can be customized for the needs of each customer. Its main purpose is to ensure the flow of products and goods throughout the supply chain, saving time and costs. It aims to ensure that products reach the final recipient in the shortest possible time and at the lowest possible cost, offering quality of service and specialization, depending on the requirements and needs of the goods that are being transported. Furthermore, by combining its know-how and experience with flexible practices, the company aims to ensure its adaptation to the constantly changing task environment.

To support and improve its operations and services, the company uses a variety of information systems and software applications. The most important ones include a warehouse management system (WMS), an enterprise resource planning (ERP) system, and a customer relationship management (CRM) system. These are the core business systems that the company uses. The WMS handles and monitors the warehouse processes and procedures, while the ERP system supports the trading and accounting procedures. It also 
handles issues related to customs duties. An additional important application that the company uses is "proof of delivery", providing a confirmation when a product reaches its destination. This is supported by the use of POD technology, which is connected to the WMS system and has the ability to show real-time data and indicate when the products reach their final destination.

"Information Systems are an integral part of the Supply Chain Management processes and a prerequisite for their efficient operation",

IT manager

The above systems can collaborate efficiently with the SSCM resources, such as fleet management, enabling the calculation of the "carbon footprint" (contributing to the decrease in emissions - environmental pillar), and the measurement of the temperature of transported goods by specific refrigerated trucks. The data, collected with thermostats and with appropriate software, enable the monitoring of the transport conditions. All these measurements form the characteristics that follow the product until it reaches its final recipient (traceability). Traceability is especially important for reverse logistics, as it facilitates the process of recovering the defective products, creating value for the customer. Furthermore, the ORBIT Sales Tax software (which belongs to the "ERP family" and is produced by Orbit Software Solutions in Athens, Greece), used by the accounting department, provides the company with critical financial data (economic pillar) and helps the company to make strategic decisions. Finally, the education and training of the members of the company have enabled them to adjust to the needs of the task environment, have led to the better management of human resources (HRM resources), and improved working conditions (social pillar). These resources in collaboration with the company's philosophy to work only with partners who also follow the green philosophy have led to increased "sustainability capabilities".

As a result, the combination of the above company's resources (IT, HRM, and SSCM resources) led to the creation of "sustainable capabilities", which did not suddenly appear and were not purchased for some monetary value but were developed over time, as the "know-how" of the firm was acquired throughout its operation. Thus, according to the logistics manager of the company, all three categories of sustainability capabilities, namely economic, social, and environmental capabilities, were created.

The economic capability is derived from results emerging from a range of activities involving the exchange of information and cooperation with partners, as well as key elements of interorganizational relationships, such as mutual trust and long-term partnership. These increase the efficiency of transactions, lead to better inventory management, and decrease operational costs. Environmental capability is associated with a company's ability to manage the various environmental issues that arise in the supply chain (e.g., optimal route in order to reduce $\mathrm{CO}_{2}$ emissions and gas consumption). Finally, social capability refers to the company's ability to handle various social issues (both internally and externally), such as the contribution to society, respecting the wishes and preferences of customers who expect the company to be eco-friendly, and the collaboration with partners that follow the respective EU regulations and have green policies.

These capabilities create a sustainability value, which is reflected and influenced by the community, where customers expect the company to have environmental consciousness and a green policy orientation. Thus, the company aims to follow the EU regulations regarding the management of its fleet, choosing new vehicle technologies used by the company's partners, and aiming to reduce air pollution and carbon emissions. These lead to increased customer satisfaction and contribute to their loyalty.

"Customers nowadays are extremely environmentally aware and demand from a company and its partners firstly to respect the environment and the society and secondly to achieve financial results",

account manager 
Furthermore, the attainment of sustainability value, in combination with the use of information systems, creates strong "internal business performance". This means that the internal process execution times are drastically reduced due to the technological infrastructure of the company. For example, the use of PDAs by each employee in the warehouse, which are automatically connected via wi-fi to the PC terminals (located in the offices of the company), enable the efficient and accurate exchange of the necessary information between them. Thus, procedures that are part of the daily routine, especially in the warehouse areas, are ameliorated and automated, giving the ability to execute operations more effectively.

"The collaboration of Information Systems and Sustainable policies increases the business performance of the company. This is shown through the use of KPIs, which are also used to indicate customer satisfaction",

logistics director

However, as shown in Figure 4, the attained sustainability value cannot necessarily lead to competitive advantage. As the logistics manager of the company stated, similar technologies and practices are also embraced by competitors and cannot provide such an advantage to the company.

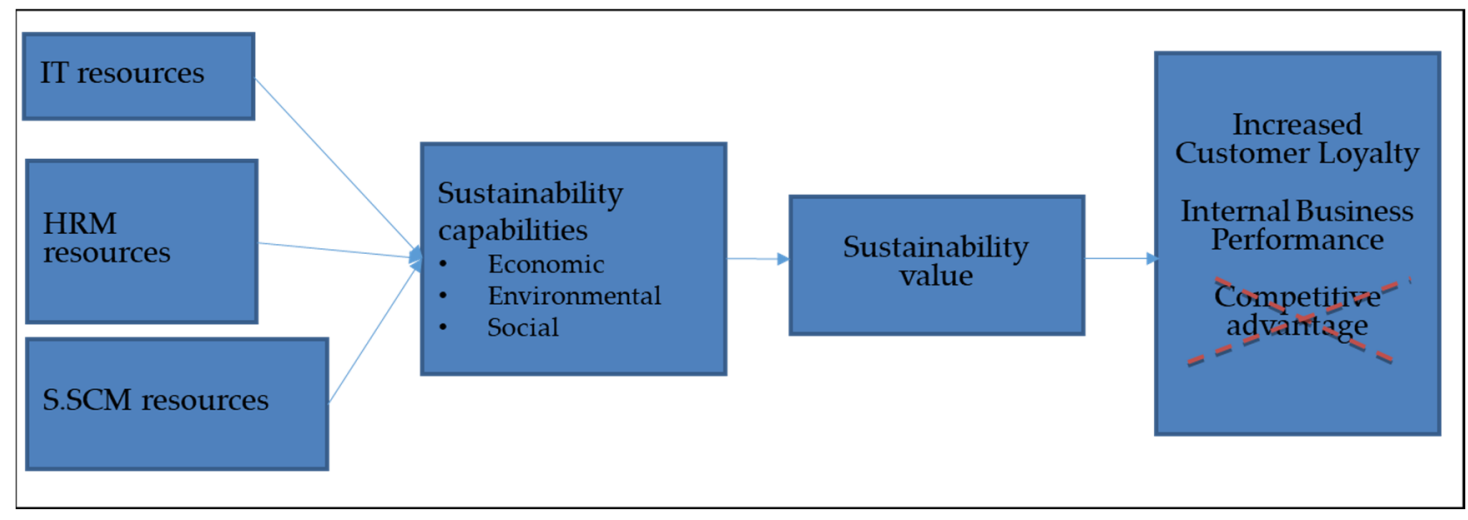

Figure 4. Sustainability value.

Nevertheless, IT resources combined with HRM and SSCM resources have led to value creation, which has led to increased business performance. They may not have led to a competitive advantage, but they certainly improved the image of the company in the eyes of its customers.

The future plans of the company include the further expansion of its technological infrastructure. The company intends to embrace technological advances, such as cloudbased services. By transferring everything to the cloud, the company will not need to own servers; this will save space and consume less electrical energy. Additionally, the company intends to adopt EDI services to better communicate with its suppliers, partners, and customers. By doing so, information sharing, such as picking lists, deliverables, and invoices, will be increased, and collaboration with trading partners will be improved. According to Manavalan and Jayakrishna [83], sharing real-time information could enable the integration between the partners and customers and offer benefits to the entire supply chain. These new developments will further support and increase communication and the transparency of transactions, which is an important feature of the social dimension of sustainable development.

\section{Discussion}

The results of this case study, summarized in Figure 5, revealed that the use of information systems and the adoption of sustainability practices in collaboration with trading partners enabled the company to increase its business performance, achieve economic 
and environmental results, and improve its customer loyalty but not necessarily gain competitive advantage.

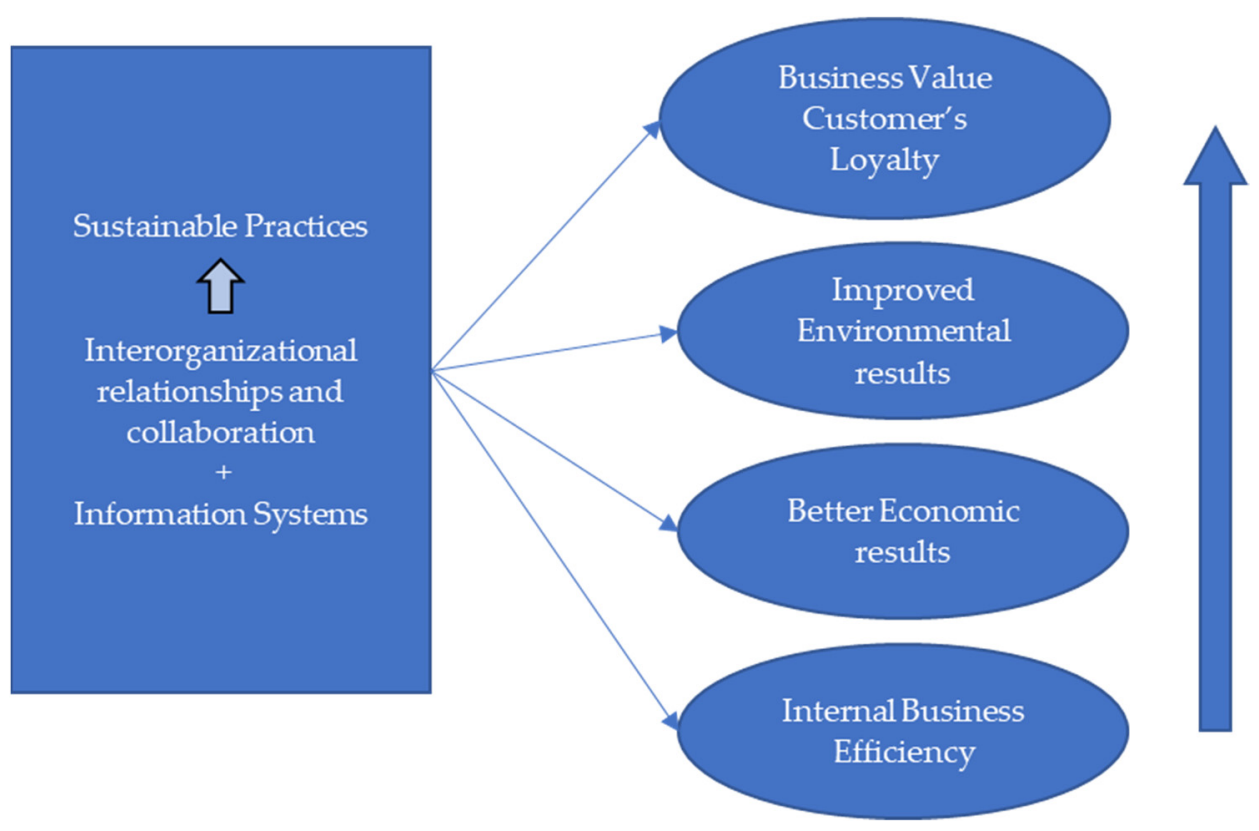

Figure 5. Increase in performance.

More specifically, the results showed that the use of information systems led the company to improve its supply chain management processes [99] and ameliorate its interorganizational relationships with trading partners. Additional benefits to the entire supply chain are expected with the adoption of EDI services, which will further facilitate information sharing $[56,102,103]$ and collaboration [104]. Furthermore, the use of IS combined with strong interorganizational relationships and collaboration led to the development of sustainability practices and provided both tangible and intangible resources (IT and SSCM resources) [13]. According to the RBV theory, if the combination of these resources is rare, adds value to the company, is very difficult to imitate, and is exploited by the company, a sustainable competitive advantage can eventually be achieved $[73,74]$. However, in this specific case study, a sustainable competitive advantage was not directly gained, as the information systems used and the sustainability practices developed were also adopted by competitors.

Although the implementation and use of different systems (e.g., WMS, ERP, and CRM) in the company led to important changes in the area of logistics and financial management, similar systems were also adopted by competitors, providing them with comparable advantages [68]. Furthermore, although sustainability practices were implemented in collaboration with trading partners, similar practices were developed by the supply chains of competitors, following the EU directives.

However, as mentioned above, the proper use of information systems in supply chain management processes and the strategic alignment with trading partners, in combination with the adoption of sustainable practices, enabled the company to gain sustainability capabilities $[6,13]$. As a result, the company gained several advantages, such as increased business efficiency $[5-8,105]$ (resulting from the automation and acceleration of processes, data accuracy, better response to customers, etc.), better economic results (resulting from cost savings), and improved environmental results (e.g., decreased $\mathrm{CO}_{2}$ emissions), as well as increased business value and sustainability value to customers and society. Due to these results, the company gained increased customer satisfaction and loyalty [104], leading to a stable and potentially increased market share. 
Therefore, the results of our study are not aligned with previous research arguing that IS-enabled SSCM leads to competitive advantage $[6,14]$. They lead to the development of an altered conceptual framework (Figure 4) showing that sustainability capabilities can lead to increased sustainability and business value but not necessarily to competitive advantage. Furthermore, they show that the combination of IS with sustainability practices can bring important advantages (Figure 5), such as increased business performance [5-8], financial performance [106], and environmental performance [105] and increased customer satisfaction and loyalty [107], ensuring the survivability of companies and of their supply chains.

\section{Conclusions and Limitations}

The aim of this research is to contribute to the literature by exploring the relationship between IS and SSCM practices and examining whether their combination could lead not only to increased business performance but also to competitive advantage. After finding the existence of different points of view in the literature, the authors decided to conduct a single-case study to examine the subject of study in depth. The results showed that although the benefits of the company from both the use of information systems and the adoption of sustainability practices were varied, they did not lead to a competitive advantage, at least not directly. Therefore, the results of this research are not completely aligned with the research conducted by Dao et al. [11], Mastos et al. [15], and Marinagi et al. [12] and tend to agree with the views and conclusions of the authors who focus on the increased business performance as a key asset of using technologies to support sustainability practices [5-10].

According to the RBV theory and the analysis of the relationship between IT, SCM, and sustainability, it seems that the proper use and exploitation of IT, in conjunction with HRM and SCM resources, as well as the right alignment with trading partners, enable both the company and its partners to achieve business advantages. More specifically, the results of this study showed that through interorganizational collaboration and the proper use of IS, the company achieved a significant increase in both financial and operational performance and improved its environmental performance while creating an 'environmentally friendly' image for consumers. These outcomes led to increased customer satisfaction and loyalty. They have also led to social benefits, arising from the green policies that have been developed and applied across the years in cooperation with trading partners. However, it is important to note that the use of information systems in combination with sustainability practices adopted in this specific company did not lead to sustainable competitive advantage, as similar technologies and practices are also adopted by other companies in the industry.

The fact that this study was conducted in the Greek market did not seem to affect the research results. Although companies in Greece tend to slightly lag behind with the adoption of new technologies, the results that they finally achieve are similar to those of foreign companies. Especially in the logistics sector, companies collaborate and are influenced by partners or customers that are multinational companies based either in Greece or in Europe. Furthermore, they follow policies and guidelines related to the goals of sustainable development, which are mostly determined at a European level.

In summary, the study showed that by using appropriate technologies and information systems, companies are able not only to support their supply chain processes and implement sustainability practices but also to increase their performance and improve customer satisfaction and loyalty. One could argue that these results could additionally lead to sustainable competitive advantage, but only if the combination of IT, HRM, and SCM resources is unique and not easily imitated by competitors.

The main limitation of this study is the lack of generalizability of the research results. This is the main disadvantage of this research methodology, which is, however, counterbalanced by the ability to analyze a phenomenon in depth. Nevertheless, as the results presented in this paper are part of an ongoing study, this limitation will be addressed through future research. To draw more generalizable results, the authors intend to examine 
additional cases/companies with varied characteristics. The realization of a multiple-case design will enable the conduct of a comparative analysis leading to safer conclusions. It would also enable the examination of further sustainability practices, focusing on the ones related to the social dimension of SSCM. Additional data will also be collected in the future through a large-scale survey, which will lead to even more generalizable results. In conclusion, we could argue that this research, through the conduct of a single-case study, provided insight that could form the basis for future research in the field of information systems and SSCM.

Author Contributions: Conceptualization, A.S. and E.K.; methodology, A.S. and E.K.; validation, A.S., E.K. and G.K.; formal analysis, A.S. and E.K.; investigation, A.S. and G.K.; resources, A.S. and G.K.; data curation, E.K.; writing—original draft preparation, A.S. and E.K.; writing—review and editing, A.S. and E.K.; visualization, A.S. and E.K.; supervision E.K.; project administration, A.S. and E.K.; funding acquisition, E.K. All authors have read and agreed to the published version of the manuscript.

Funding: This work has been partly supported by the University of Piraeus Research Center.

Institutional Review Board Statement: Not applicable.

Informed Consent Statement: Not applicable.

Data Availability Statement: Data available on request due to privacy restrictions.

Acknowledgments: This work has been partly supported by the University of Piraeus Research Center.

Conflicts of Interest: The authors declare no conflict of interest.

\section{Appendix A}

Table A1. Definitions of SSCM.

\begin{tabular}{|c|c|c|c|c|}
\hline & Papers & Authors & Journal & Year \\
\hline 1 & $\begin{array}{c}\text { "... as the management of supply chain operations, } \\
\text { resources, information, and funds in order to maximize the } \\
\text { supply chain profitability while at the same time minimizing } \\
\text { the environmental impacts and maximizing the social } \\
\text { well-being." [108] (p. 70) }\end{array}$ & $\begin{array}{l}\text { Hassini, E., Surti, C., } \\
\text { and Searcy, C. }\end{array}$ & $\begin{array}{l}\text { International Journal of } \\
\text { Production Economics }\end{array}$ & 2012 \\
\hline 2 & $\begin{array}{l}\text { “. . SSCM is an activity that helps to modify traditional } \\
\text { supply chains. This modification is part of the sustainable } \\
\text { development of an organization. A truly sustainable } \\
\text { organization can simultaneously achieve social, } \\
\text { environmental and economic benefits." [109] (p. 633) }\end{array}$ & $\begin{array}{l}\text { Moktadir, M.A., Ali, } \\
\text { S.M., Rajesh, R., and } \\
\text { Paul, S.K. }\end{array}$ & $\begin{array}{l}\text { Journal of Cleaner } \\
\text { Production }\end{array}$ & 2018 \\
\hline 3 & $\begin{array}{l}\text { “... SSCM as the strategic, transparent integration and } \\
\text { achievement of an organization's social, environmental, and } \\
\text { economic goals in the systemic coordination of key } \\
\text { interorganizational business processes for improving the } \\
\text { long-term economic performance of the individual company } \\
\text { and its supply chains." [37] (p. 368) }\end{array}$ & $\begin{array}{c}\text { Carter, C.R., Rogers, } \\
\text { D.S. }\end{array}$ & $\begin{array}{l}\text { International Journal of } \\
\text { Physical Distribution \& } \\
\text { Logistics Management }\end{array}$ & 2008 \\
\hline 4 & $\begin{array}{l}\text { “... sustainable supply chain management as the } \\
\text { management of material, information and capital flows as } \\
\text { well as cooperation among companies along the supply } \\
\text { chain while taking goals from all three dimensions of } \\
\text { sustainable development, i.e., economic, environmental and } \\
\text { social, into account which are derived from customer and } \\
\text { stakeholder requirements." [38] (p. 1700) }\end{array}$ & $\begin{array}{l}\text { Stefan Seuring, } \\
\text { Martin Müller }\end{array}$ & $\begin{array}{l}\text { Journal of Cleaner } \\
\text { Production }\end{array}$ & 2008 \\
\hline
\end{tabular}


Table A1. Cont.

\begin{tabular}{|c|c|c|c|c|}
\hline & Papers & Authors & Journal & Year \\
\hline 5 & $\begin{array}{l}\text { "SSCM is defined as the incorporation of the three pillars of } \\
\text { sustainability (including environmental, economic, and } \\
\text { social dimensions) in managing the material and information } \\
\text { flow and in establishing cooperation among the members of } \\
\text { the supply chain; the objective is to minimize negative } \\
\text { environmental and social impacts and to simultaneously } \\
\text { enhance economic performance." [110] (p. 220) }\end{array}$ & $\begin{array}{l}\text { Govindan, K., Jafarian, } \\
\text { A., and Nourbakhsh, V. }\end{array}$ & $\begin{array}{l}\text { Computers \& } \\
\text { Operations Research }\end{array}$ & 2019 \\
\hline 6 & $\begin{array}{l}\text { "The creation of coordinated supply chains through } \\
\text { the voluntary } \\
\text { integration of economic, environmental, and } \\
\text { social considerations } \\
\text { with key inter-organizational business systems designed to } \\
\text { efficiently and effectively manage the material, information, } \\
\text { and capital flows associated with the procurement, } \\
\text { production, and distribution of products or services in } \\
\text { order to } \\
\text { meet stakeholder requirements and improve the profitability, } \\
\text { competitiveness, and resilience of the organization over the } \\
\text { short- and long-term." [38] (p. 339) }\end{array}$ & Ahi, P., Searcy, C. & $\begin{array}{l}\text { Journal Cleaner } \\
\text { Production }\end{array}$ & 2013 \\
\hline 7 & $\begin{array}{l}\text { “... SSCM is the designing, organizing, coordinating, and } \\
\text { controlling of sup-ply chains to become truly sustainable } \\
\text { with the minimum expectation of a truly sustainable supply } \\
\text { chain being to maintain economic viability, while doing no } \\
\text { harm to social or environmental systems." [111] (p. 45) }\end{array}$ & $\begin{array}{l}\text { Pagell, M. and } \\
\text { Shevchenko, A. }\end{array}$ & $\begin{array}{l}\text { Journal of Supply } \\
\text { Chain Management }\end{array}$ & 2014 \\
\hline 8 & $\begin{array}{l}\text { “SSCM adds sustainability to existing supply chain } \\
\text { management processes, to consider environmental, social } \\
\text { and economic impacts of business activities." [112] (p. 260) }\end{array}$ & $\begin{array}{l}\text { Font, X., Tapper, R., } \\
\text { Schwartz, K., Kornilaki, } \\
\text { M. }\end{array}$ & $\begin{array}{l}\text { Business strategy and } \\
\text { the environment }\end{array}$ & 2008 \\
\hline 9 & $\begin{array}{l}\text { "Sustainable Supply Chain Management (SSCM) extends the } \\
\text { traditional concept of Supply Chain Management by adding } \\
\text { environmental and social/ethical aspects." [113] (p. 142) }\end{array}$ & $\begin{array}{l}\text { Wittstruck, D., and } \\
\text { Teuteberg, F. }\end{array}$ & $\begin{array}{l}\text { Corporate Social } \\
\text { Responsibility and } \\
\text { Environmental } \\
\text { Management }\end{array}$ & 2012 \\
\hline 10 & $\begin{array}{l}\text { “.. sustainable supply chain is the way to come up with a } \\
\text { set of organizational innovations and policies on term of } \\
\text { supply chain planning and management taking into account } \\
\text { sustainability indicators." [114] (p. 764) }\end{array}$ & $\begin{array}{l}\text { Allaoui, H., Guo, Y., } \\
\text { and Sarkis, J. }\end{array}$ & $\begin{array}{l}\text { Journal of Cleaner } \\
\text { Production }\end{array}$ & 2019 \\
\hline 11 & $\begin{array}{l}\text { "... supply chain sustainability integration as the degree to } \\
\text { which a manufacturer strategically collaborates with its } \\
\text { supply chain partners and collaboratively manages intra- } \\
\text { and inter-organization processes for sustainability. The goal } \\
\text { is to achieve economic, environmental and social } \\
\text { sustainability by integrating flows of products and services, } \\
\text { information, capital and decisions, to provide maximum } \\
\text { value to multiple stakeholder groups." [115] (p. 223) }\end{array}$ & Wolf, J. & $\begin{array}{l}\text { Journal of Business } \\
\text { Ethics }\end{array}$ & 2011 \\
\hline 12 & $\begin{array}{c}\text { "... sustainable supply chain management is then the } \\
\text { specific managerial actions that are taken to make the supply } \\
\text { chain more sustainable with an end goal of creating a truly } \\
\text { sustainable chain." [116] (p. 38) }\end{array}$ & Pagell, M. and $\mathrm{Wu}, \mathrm{Z}$. & $\begin{array}{l}\text { Journal of Supply } \\
\text { Chain Management }\end{array}$ & 2009 \\
\hline 13 & $\begin{array}{c}\text { "Sustainable Supply Chain Management (SSCM) is an } \\
\text { importantstrategy that supports organizations in improving } \\
\text { the overallperformance." [46] (p. 85) }\end{array}$ & $\begin{array}{l}\text { Al-Odeh, M., and } \\
\text { Smallwood, J. }\end{array}$ & $\begin{array}{l}\text { International Journal of } \\
\text { Computational } \\
\text { Engineering \& } \\
\text { Management }\end{array}$ & 2012 \\
\hline
\end{tabular}




\section{References}

1. Rinaldi, M.; Caterino, M.; Fera, M.; Manco, P.; Macchiaroli, R. Technology selection in green supply chains-the effects of additive and traditional manufacturing. J. Clean. Prod. 2020, 282, 124554. [CrossRef]

2. Large, R.O.; Thomsen, C.G. Drivers of green supply management performance: Evidence from Germany. J. Purch. Supply Manag. 2011, 17, 176-184. [CrossRef]

3. Saeed, M.A.; Kersten, W. Drivers of sustainable supply chain management: Identification and classification. Sustainability 2020, 11, 1137. [CrossRef]

4. Helo, P.; Szekely, B. Logistics information systems: An analysis of software solutions for supply chain co-ordination. Ind. Manag. Data Syst. 2005, 105, 5-18. [CrossRef]

5. Peng, J.; Quan, J.; Zhang, G.; Dubinsky, A.J. Mediation effect of business process and supply chain management capabilities on the impact of IT on firm performance: Evidence from Chinese firms. Int. J. Inf. Manag. 2016, 36, 89-96. [CrossRef]

6. Benitez-Amado, J.; Llorens-Montes, F.J.; Fernandez-Perez, V. The relationship between IT infrastructure leveraging, talent management and operational sustainability, and their effects on the business value of the operations strategy. In Proceedings of the 19th Americas Conference on Information Systems, Chicago, IL, USA, 15-17 August 2013; pp. 1-8.

7. Melián-Alzola, L.; Fernández-Monroy, M.; Hidalgo-Peñate, M. Information technology capability and organisational agility: A study in the Canary Islands hotel industry. Tour. Manag. Perspect. 2020, 33, 100606. [CrossRef]

8. Sharma, M.; Kamble, S.; Mani, V.; Sehrawat, R.; Belhadi, A.; Sharma, V. Industry 4.0 adoption for sustainability in multi-tier manufacturing supply chain in emerging economies. J. Clean. Prod. 2021, 281, 125013. [CrossRef]

9. Eren, A.S.; Balkar, O.E. Üretim Yönetim Sistemlerindeki Kritik Başarı Faktörlerinin Rekabete Etkisi: Metal Sektöründe Bir Araştırma. Itobiad J. Hum. Soc. Sci. Res. 2020, 9, 3542-3567.

10. Pirmanta, P.; Tarigan, Z.; Basana, S. The effect of ERP on firm performance through information quality and supply chain integration in COVID-19 era. Uncertain Supply Chain Manag. 2021, 9, 659-666. [CrossRef]

11. Dao, V.; Langella, I.; Carbo, J. From green to sustainability: Information Technology and an integrated sustainability framework. J. Strateg. Inf. Syst. 2011, 20, 63-79. [CrossRef]

12. Marinagi, C.; Trivellas, P.; Sakas, D.P. The impact of information technology on the development of supply chain competitive advantage. Procedia Soc. Behav. Sci. 2014, 147, 586-591. [CrossRef]

13. Gold, S.; Seuring, S.; Beske, P. Sustainable supply chain management and inter-organizational resources: A literature review. Corp. Soc. Responsib. Environ. Manag. 2010, 17, 230-245. [CrossRef]

14. Baah, C.; Jin, Z. Sustainable supply chain management and organizational performance: The intermediary role of competitive advantage. J. Manag. Sustain. 2019, 9, 119-131. [CrossRef]

15. Mastos, T.D.; Nizamis, A.; Vafeiadis, T.; Alexopoulos, N.; Ntinas, C.; Gkortzis, D.; Papadopoulos, A.; Ioannidis, D.; Tzovaras, D. Industry 4.0 sustainable supply chains: An application of an IoT enabled scrap metal management solution. J. Clean. Prod. 2020, 269, 122377. [CrossRef]

16. Brundtland, G.H. Our common future-Call for action. Environ. Conserv. 1987, 14, 291-294. [CrossRef]

17. Emas, R. The Concept of Sustainable Development: Definition and Defining Principles; Brief for GSDR; Florida International University: Miami, FL, USA, 2015.

18. Robert, K.W.; Parris, T.M.; Leiserowitz, A.A. What is sustainable development? Goals, indicators, values, and practice. Environ. Sci. Policy Sustain. Dev. 2005, 47, 8-21. [CrossRef]

19. Halog, A.; Manik, Y. Advancing integrated systems modelling framework for life cycle sustainability assessment. Sustainability 2011, 3, 469-499. [CrossRef]

20. Scheidel, A.; Temper, L.; Demaria, F.; Martínez-Alier, J. Ecological distribution conflicts as forces for sustainability: An overview and conceptual framework. Sustain. Sci. 2018, 13, 585-598. [CrossRef]

21. Stroumpoulis, A. Information Systems in Green Supply Chain Management. Master's Thesis, University of Piraeus, Pireas, Greece, November 2018.

22. Al Amosh, H.A.M.; Mansor, N. Sustainability and corporate reporting: A review on environmental and social accounting disclosure. Int. J. Account. 2018, 3, 78-87.

23. Joshi, S.; Li, Y. What is corporate sustainability and how do firms practice it? A management accounting research perspective. J. Manag. Account. Res. 2016, 28,1-11. [CrossRef]

24. Gilbert, D.U.; Rasche, A.; Waddock, S. Accountability in a global economy: The emergence of international accountability standards. Bus. Ethics Q. 2011, 21, 23-44. [CrossRef]

25. Varelas, S.; Karvela, P.; Georgopoulos, N. The Impact of Information Technology and Sustainable Strategies in Hotel Branding, Evidence from the Greek Environment. Sustainability 2021, 13, 8543. [CrossRef]

26. Miles, M.P.; Munilla, L.S. The potential impact of social accountability certification on marketing: A short note. J. Bus. Ethics 2004, 50,1-11. [CrossRef]

27. Loučanová, E.; Šupín, M.; Čorejová, T.; Repková-Štofková, K.; Šupínová, M.; Štofková, Z.; Olšiaková, M. Sustainability and Branding: An Integrated Perspective of Eco-innovation and Brand. Sustainability 2021, 13, 732. [CrossRef]

28. Choi, S.; Ng, A. Environmental and economic dimensions of sustainability and price effects on consumer responses. J. Bus. Ethics 2011, 104, 269-282. [CrossRef] 
29. Wang, Y.; Chen, Y.; Benitez-Amado, J. How information technology influences environmental performance: Empirical evidence from China. Int. J. Inf. Manag. 2015, 35, 160-170. [CrossRef]

30. Davidson, M. Social sustainability: A potential for politics? Local Environ. 2009, 14, 607-619. [CrossRef]

31. Boström, M. A missing pillar? Challenges in theorizing and practicing social sustainability: Introduction to the special issue. Sustain. Sci. Pract. Policy 2012, 8, 3-14. [CrossRef]

32. Mani, V.; Gunasekaran, A.; Delgado, C. Enhancing supply chain performance through supplier social sustainability: An emerging economy perspective. Int. J. Prod. Econ. 2018, 195, 259-272. [CrossRef]

33. Zadek, S. The path to corporate responsibility. In Corporate Ethics and Corporate Governance; Springer: Berlin/Heidelberg, Germany, 2007; pp. 159-172.

34. Klassen, R.D.; Vereecke, A. Social issues in supply chains: Capabilities link responsibility, risk (opportunity), and performance. Int. J. Prod. Econ. 2012, 140, 103-115. [CrossRef]

35. Seman, N.A.A.; Zakuan, N.; Jusoh, A.; Arif, M.S.M.; Saman, M.Z.M. Green supply chain management: A review and research direction. Int. J. Manag. Value Supply Chains 2012, 3, 1-18. [CrossRef]

36. Tate, W.L.; Ellram, L.M.; Kirchoff, J.F. Corporate social responsibility reports: Thematic analysis related to supply chain management. J. Supply Chain Manag. 2010, 46, 19-44. [CrossRef]

37. Bhattacharya, C.B.; Sen, S. Doing better at doing good: When, why, and how consumers respond to corporate social initiatives. Calif. Manag. Rev. 2004, 47, 9-24. [CrossRef]

38. Seuring, S.; Müller, M. From a literature review to a conceptual framework for sustainable supply chain management. J. Clean. Prod. 2008, 16, 1699-1710. [CrossRef]

39. Carter, C.R.; Rogers, D.S. A framework of sustainable supply chain management: Moving toward new theory. Int. J. Phys. Distrib. Logist. Manag. 2008, 38, 360-387. [CrossRef]

40. Rostamzadeh, R.; Govindan, K.; Esmaeili, A.; Sabaghi, M. Application of fuzzy VIKOR for evaluation of green supply chain management practices. Ecol. Indic. 2015, 49, 188-203. [CrossRef]

41. Zaid, A.A.; Jaaron, A.A.; Bon, A.T. The impact of green human resource management and green supply chain management practices on sustainable performance: An empirical study. J. Clean. Prod. 2018, 204, 965-979. [CrossRef]

42. Ahi, P.; Searcy, C. A comparative literature analysis of definitions for green and sustainable supply chain management. J. Clean. Prod. 2013, 52, 329-341. [CrossRef]

43. Li, F.; Yan, X.F.; Duan, H.F. Sustainable design of urban stormwater drainage systems by implementing detention tank and LID measures for flooding risk control and water quality management. Water Resour. Manag. 2019, 33, 3271-3288. [CrossRef]

44. Tseng, M.L. Modeling the sustainable production indicators in linguistic preferences. J. Clean. Prod. 2013, 40, 46-56. [CrossRef]

45. Varsei, M. Sustainable supply chain management: A brief literature review. J. Dev. Areas 2016, 50, 411-419. [CrossRef]

46. Al-Odeh, M.; Smallwood, J. Sustainable supply chain management: Literature review, trends, and framework. Int. J. Comput. Eng. Manag. 2012, 15, 85-90.

47. Bag, S.; Wood, L.C.; Mangla, S.K.; Luthra, S. Procurement 4.0 and its implications on business process performance in a circular economy. Resour. Conserv. Recycl. 2020, 152, 104502. [CrossRef]

48. Brdulak, H.; Brdulak, A. Challenges and Threats Faced in 2020 by International Logistics Companies Operating on the Polish Market. Sustainability 2021, 13, 359. [CrossRef]

49. Shibin, K.T.; Dubey, R.; Gunasekaran, A.; Hazen, B.; Roubaud, D.; Gupta, S.; Foropon, C. Examining sustainable supply chain management of SMEs using resource-based view and institutional theory. Ann. Oper. Res. 2020, 290, 301-326. [CrossRef]

50. Bostrom, R.P.; Heinen, J.S. MIS problems and failures: A socio-technical perspective. Part I: The causes. MIS Q. 1977, 1, 17-32. [CrossRef]

51. Piccoli, G.; Lui, T.W. The competitive impact of information technology: Can commodity IT contribute to competitive performance? Eur. J. Inf. Syst. 2014, 23, 616-628. [CrossRef]

52. Barczak, A.; Dembińska, I.; Marzantowicz, Ł. Analysis of the Risk Impact of Implementing Digital Innovations for Logistics Management. Processes 2019, 7, 815. [CrossRef]

53. De Camargo Fiorini, P.; Jabbour, C.J.C. Information systems and sustainable supply chain management towards a more sustainable society: Where we are and where we are going. Int. J. Inf. Manag. 2017, 37, 241-249. [CrossRef]

54. Gunasekaran, A.; Ngai, E.W. Information systems in supply chain integration and management. Eur. J. Oper. Res. 2004, 159, 269-295. [CrossRef]

55. Georgopoulos, N.; Kopanaki, E.; Pantazi, A.-M.; Nikolarakos, T.; Vaggelatos, I. E-Commerce: Planning and Design, 2nd ed.; Publisher E. Benou: Athens, Greece, 2013; ISBN 9789603591092.

56. Müller, J.M.; Veile, J.W.; Voigt, K.I. Prerequisites and incentives for digital information sharing in Industry 4.0—An international comparison across data types. Comput. Ind. Eng. 2020, 148, 106733. [CrossRef]

57. Javaid, M.; Haleem, A.; Singh, R.P.; Khan, S.; Suman, R. Blockchain technology applications for Industry 4.0: A literature-based review. Blockchain Res. Appl. 2021, 100027. [CrossRef]

58. Stroumpoulis, A.; Kopanaki, E.; Oikonomoy, M. The impact of blockchain technology on food waste management in the hospitality industry. In Proceedings of the ENTRENOVA, Zagreb, Croatia, 2021.

59. Kumar, P.; Singh, R.K.; Kumar, V. Managing supply chains for sustainable operations in the era of industry 4.0 and circular economy: Analysis of barriers. Resour. Conserv. Recycl. 2021, 164, 105215. [CrossRef] 
60. De Sousa Jabbour, A.B.L.; Jabbour, C.J.C.; Foropon, C.; Godinho Filho, M. When titans meet-Can industry 4.0 revolutionise the environmentally-sustainable manufacturing wave? The role of critical success factors. Technol. Forecast. Soc. Change 2018, 132, 18-25. [CrossRef]

61. Roblek, V.; Meško, M.; Krapež, A. A complex view of industry 4.0. Sage Open 2016, 6, 1-11. [CrossRef]

62. Xu, L.D.; Xu, E.L.; Li, L. Industry 4.0: State of the art and future trends. Int. J. Prod. Res. 2018, 56, 2941-2962. [CrossRef]

63. Gonzalez-Feliu, J.; Semet, F.; Routhier, J.L. Sustainable Urban Logistics: Concepts, Methods and Information Systems, 1st ed.; Springer: Berlin/Heidelberg, Germany, 2014.

64. Kagermann, H.; Wahlster, W.; Helbig, J. Recommendations for Implementing the Strategic Initiative Industrie 4.0; Final Report of the Industrie 4.0 Working Group; Forschungsunion: Berlin, Germany, 2013.

65. Müller, J.M.; Buliga, O.; Voigt, K.I. Fortune favors the prepared: How SMEs approach business model innovations in Industry 4.0. Technol. Forecast. Soc. Chang. 2018, 132, 2-17. [CrossRef]

66. Rogerson, M.; Parry, G.C. Blockchain: Case studies in food supply chain visibility. Supply Chain. Manag. Int. J. 2020, 25, 601-614. [CrossRef]

67. Birkel, H.S.; Müller, J.M. Potentials of industry 4.0 for supply chain management within the triple bottom line of sustainabilityA systematic literature review. J. Clean. Prod. 2020, 289, 125612. [CrossRef]

68. Malhotra, A.; Melville, N.P.; Watson, R.T. Spurring impactful research on information systems for environmental sustainability. MIS Q. 2013, 37, 1265-1274. [CrossRef]

69. Zhu, Q.; Sarkis, J.; Geng, Y. Green supply chain management in China: Pressures, practices and performance. Int. J. Oper. Prod. Manag. 2005, 25, 449-468. [CrossRef]

70. Saberi, S.M.; Kouhizadeh, J.S.; Shen, L. Blockchain Technology and Its Relationships to Sustainable Supply Chain Management. Int. J. Prod. Res. 2019, 57, 2117-2135. [CrossRef]

71. Bezvesilnaya, A.A.; Shadskaja, I.G.E.; Kozlova, N.A.; Shelygov, A.V.; Alekseenko, E.V. Digital technology development in tourism and hospitality industry. Eurasian J. Biosci. 2020, 14, 5561-5565.

72. Freeman, R.E.; Dmytriyev, S.D.; Phillips, R.A. Stakeholder theory and the resource-based view of the firm. J. Manag. 2021, 47, 1757-1770.

73. Wernerfelt, B. A resource-based view of the firm. Strateg. Manag. J. 1984, 5, 171-180. [CrossRef]

74. Cardeal, N.; Antonio, N.S. Valuable, rare, inimitable resources and organization (VRIO) resources or valuable, rare, inimitable resources (VRI) capabilities: What leads to competitive advantage? Afr. J. Bus. Manag. 2012, 6, 10159-10170. [CrossRef]

75. Colbert, B.A.; Kurucz, E.C. Three conceptions of triple bottom line business sustainability and the role for HRM. People Strateg. 2007, 30, 21-29.

76. Bharadwaj, A.S. A resource-based perspective on information technology capability and firm performance: An empirical investigation. MIS Q. 2000, 24, 169-196. [CrossRef]

77. Bharadwaj, S.; Bharadwaj, A.; Bendoly, E. The performance effects of complementarities between information systems, marketing, manufacturing, and supply chain processes. Inf. Syst. Res. 2007, 18, 437-453. [CrossRef]

78. Hart, S.L. A natural-resource-based view of the firm. Acad. Manag. Rev. 1995, 20, 986-1014. [CrossRef]

79. Dyer, J.H.; Singh, H. The relational view: Cooperative strategy and sources of interorganizational competitive advantage. Acad. Manag. Rev. 1998, 23, 660-679. [CrossRef]

80. Chan, T.Y.; Wong, C.W.; Lai, K.H.; Lun, V.Y.; Ng, C.T.; Ngai, E.W. Green service: Construct development and measurement validation. Prod. Oper. Manag. 2016, 25, 432-457. [CrossRef]

81. Mandal, S.; Scholar, V. Supply Chain Innovation: A dynamic Capability Perspective; American Council of Supply Chain Management Professionals: Lombard, IL, USA, 2011; pp. 1-10.

82. Morash, E.A. Supply chain strategies, capabilities, and performance. Transp. J. 2001, 41, 37-54.

83. Egan, M.E.; Shera, J.H. Foundations of a theory of bibliography. Libr. Q. 1952, 22, 125-137.

84. Achi, A.; Salinesi, C.; Viscusi, G. Innovation capacity and the role of information systems: A qualitative study. J. Manag. Anal. 2016, 3, 333-360. [CrossRef]

85. Webster, J.; Watson, R.T. Analyzing the Past to Prepare for the Future: Writing a Literature Review. MIS Q. 2002, 26, xiii-xxiii.

86. Pozzebon, M.; Petrini, M.; de Mello, R.B.; Garreau, L. Unpacking researchers' creativity and imagination in grounded theorizing: An exemplar from IS research. Inf. Organ. 2011, 21, 177-193. [CrossRef]

87. Sahebalzamani, S.; Bertella, G. Business models and sustainability in nature tourism: A systematic review of the literature. Sustainability 2018, 10, 3226. [CrossRef]

88. Walsham, G. The emergence of interpretivism in IS research. Inf. Syst. Res. 1995, 6, 376-394. [CrossRef]

89. Walsham, G. Doing interpretive research. Eur. J. Inf. Syst. 2006, 15, 320-330. [CrossRef]

90. Chen, W.; Hirschheim, R. A paradigmatic and methodological examination of information systems research from 1991 to 2001. Inf. Syst. J. 2004, 14, 197-235. [CrossRef]

91. Walsham, G.; Han, C.K. Information systems strategy formation and implementation: The case of a central government agency. Account. Manag. Inf. Technol. 1993, 3, 191-209.

92. Corbin, J.; Strauss, A. Basics of Qualitative Research: Techniques and Procedures for Developing Grounded Theory, 3rd ed.; Sage Publications: Thousand Oaks, CA, USA, 2008. 
93. Daymon, C.; Holloway, I. Qualitative Research Methods in Public Relations and Marketing Communications, 2nd ed.; Routledge: London, UK; Taylor \& Francis Group: New York, NY, USA, 2010.

94. Kopanaki, E. Examining Organisational Flexibility in an Interorganisational Context: A Case Study of a Grocery Retail Supply Chain. Ph.D. Thesis, London School of Economics and Political Science, London, UK, October 2008.

95. Eisenhardt, K.M. Building theories from case study research. Acad. Manag. Rev. 1989, 14, 532-550. [CrossRef]

96. Cavaye, A.L. Case study research: A multi-faceted research approach for IS. Inf. Syst. J. 1996, 6, 227-242. [CrossRef]

97. Perry, C. Processes of a case study methodology for postgraduate research in marketing. Eur. J. Mark. 1998, 32, 785-802. [CrossRef]

98. Rowley, J. Using case studies in research. Manag. Res. News 2002, 25, 16-27. [CrossRef]

99. Klein, H.K.; Myers, M.D. A set of principles for conducting and evaluating interpretive field studies in information systems. MIS Q. 1999, 23, 67-93. [CrossRef]

100. Cohen, L.; Manion, L.; Morrison, K. Research Methods in Education; Routledge: London, UK, 2011.

101. Oakley, A. Gender, methodology and people's ways of knowing: Some problems with feminism and the paradigm de-bate in social science. Sociology 1998, 32, 707-731. [CrossRef]

102. Williamson, E.A.; Harrison, D.K.; Jordan, M. Information systems development within supply chain management. Int. J. Inf. Manag. 2004, 24, 375-385. [CrossRef]

103. Li, D.; Fast-Berglund, Å.; Paulin, D. Current and future Industry 4.0 capabilities for information and knowledge sharing. Int. J. Adv. Manuf. Technol. 2019, 105, 3951-3963. [CrossRef]

104. Manavalan, E.; Jayakrishna, K. A review of Internet of Things (IoT) embedded sustainable supply chain for in-dustry 4.0 requirements. Comput. Ind. Eng. 2019, 127, 925-953. [CrossRef]

105. Dev, N.K.; Shankar, R.; Qaiser, F.H. Industry 4.0 and circular economy: Operational excellence for sustainable reverse supply chain performance. Resour. Conserv. Recycl. 2020, 153, 104583. [CrossRef]

106. Yu, Y.; Huo, B.; Zhang, Z.J. Impact of information technology on supply chain integration and company performance: Evidence from cross-border e-commerce companies in China. J. Enterp. Inf. Manag. 2021, 34, 460-489. [CrossRef]

107. Olatunji, O.O.; Ayo, O.O.; Akinlabi, S.; Ishola, F.; Madushele, N.; Adedeji, P.A. Competitive advantage of carbon efficient supply chain in manufacturing industry. J. Clean. Prod. 2019, 238, 117937. [CrossRef]

108. Hassini, E.; Surti, C.; Searcy, C. A literature review and a case study of sustainable supply chains with a focus on metrics. Int. J. Prod. Econ. 2012, 140, 69-82. [CrossRef]

109. Moktadir, M.A.; Ali, S.M.; Rajesh, R.; Paul, S.K. Modeling the interrelationships among barriers to sustainable supply chain management in leather industry. J. Clean. Prod. 2018, 181, 631-651. [CrossRef]

110. Govindan, K.; Jafarian, A.; Nourbakhsh, V. Designing a sustainable supply chain network integrated with vehicle routing: A comparison of hybrid swarm intelligence metaheuristics. Comput. Oper. Res. 2019, 110, 220-235. [CrossRef]

111. Pagell, M.; Shevchenko, A. Why research in sustainable supply chain management should have no future. J. Supply Chain Manag. 2014, 50, 44-55. [CrossRef]

112. Font, X.; Tapper, R.; Schwartz, K.; Kornilaki, M. Sustainable supply chain management in tourism. Bus. Strategy Environ. 2008, 17, 260-271. [CrossRef]

113. Wittstruck, D.; Teuteberg, F. Understanding the success factors of sustainable supply chain management: Empirical evidence from the electrics and electronics industry. Corp. Soc. Responsib. Environ. Manag. 2012, 19, 141-158. [CrossRef]

114. Allaoui, H.; Guo, Y.; Sarkis, J. Decision support for collaboration planning in sustainable supply chains. J. Clean. Prod. 2019, 229, 761-774. [CrossRef]

115. Wolf, J. Sustainable supply chain management integration: A qualitative analysis of the German manufacturing industry. J. Bus. Ethics 2011, 102, 221-235. [CrossRef]

116. Pagell, M.; Wu, Z. Building a more complete theory of sustainable supply chain management using case studies of 10 exemplars. J. Supply Chain Manag. 2009, 45, 37-56. [CrossRef] 